\title{
Influence of Magnetic Water on Self-compacting Concrete Using Sulphate Resisting Cement
}

\author{
Dara Easwar Karthik*, Pattela Mrudunayani, Sayana Veera Venkata Konda Babu \\ Department of Civil Engineering, Vignan's Lara Institute of Technology \& Science, Vadlamudi, Guntur 522213, India
}

Corresponding Author Email: darakarthik119@gmail.com

https://doi.org/10.18280/acsm.430511

Received: 9 July 2019

Accepted: 16 September 2019

\section{Keywords:}

magnetic water, micro steel fibers, metakaolin, compressive strength, tensile strength, self-compacting concrete, sulphate resisting cement

\section{INTRODUCTION}

It is generally observed that the traditional concrete is framed with the compaction of concrete which is often seen as a default. Irrespective of the building structures, it is known fact that the concrete material which must be sturdy enough and compacted be used. The compacting of concrete includes the following procedure: Removal of entrapped air to the maximum density and ensuring attaining that status [1]. Ensure that the steel reinforcement and formwork must be in full contact with these two [2]. These two strengthening points must be ensured so as to strengthen the final product. It is clearly highlighted that through the external force vibrations, the compacting of the conventional concrete is performed. These vibrations are externally emphasized though they are highly incapable of reinforcing of intensive engineering, deep structural members and wall element, where the concrete block strengthens so as to avoid problems like the mechanical properties, durability and quality and enable to complete and reduce the above said problems. Apart from all the above, it is also observed that in this research paper, that if the workability is poor, the high quality of infrastructure is utilized [3]. Moreover, in majority of the cases, it depends on the skilled workers and more energy is emphasized to form concrete shapes. It is more important to develop workability along with the compatibility with the concrete which is also named as self-consolidating concrete, self-leveling concrete, or vibration-free concrete. This has low yield stress, high deformability and moderate viscosity. One can assume that the uniform suspension of solid particles during the transportation and placement until the concrete sets, the above said one is needed with little or no vibration [4]. This self consolidating concrete can be densely filled into every corner of a formwork, totally by means of its own weight without the need for vibrations to compaction for improving the self compacting concrete properties with low cost by using magnetic water. However, the price and expenses of this method is not comparable with their advantages. Thus, most of the researchers majorly focus and concentrate on producing economical concrete with higher strength using new philosophies in designing methods through modern techniques such as magnetic water sources. The government of Russia adopted the federal program entitled "Application of magnetic fields in National Economy", this academy created a range of documents, ordering their organizations to use magnetic technologies [5]. This is the decision made in order economize on cementing and Ferroconcrete which contains the fly ash and prepared with magnetic water that increases by more than $15 \%$ when it is prepared with normal water. More over for additional strength, they propose fibres in the project [6]. Now a days fibres are most effectively used material in the concrete to reduce crack repair, reduction in shrinkage of concrete and improve the strength properties of concrete along with replaced OPC with (Sulphate Resisting Cement) SRC in the project. SRC is also one type of Portland cement in which the amount of tricalcium aluminate $\left(\mathrm{C}_{3} \mathrm{~A}\right)$ is restricted to lower than $5 \%$. The reduction of sulphate salts lowers the possibility of sulphate attack on the concrete [7]. In addition to metakaolin as an additive for provide extra strength to concrete [8].

\section{MAGNETIC WATER AND IMPORTANCE}

Magnetized water doesn't mean water has acquired magnetic strength but that it has been subjected to a magnetic field which is found to change certain properties of water. These anomalous properties of water are unique and may result in many variations of macroscopic properties. Water is not homogeneous at the nanoscale and exists as clusters depending on the temperature, pressure and existing forces. Thus, the density of the water may also change depending on the forces that dominate the conditions. The two forces that dominate are hydrogen bond and vanderwaal's forces. 
The magnetic field can break down these water clusters and reduce the bond angle and hence increase solubility. It is believed that after applying a strong magnetic field, water will show diamagnetism. Diamagnetism refers to substances that are magnetized in a way opposite to the direction of magnetic field, having pair-up electrons which cancel each other's magnetic moment because the two electrons in a pair-up rotate opposite to each other. As a result, water molecules are 'directed' to have certain orientation.

When water passes through a magnetic flux it is known as magnetized water. The level of magnetization is controlled by the method used and water purity. The structure of water is aligned in one direction after magnetization, and the molecule sizes change after the bond angle changes, therefore viscosity and surface area increase by magnetization, hence the hydration rate increases. The effect of a static magnetic field on liquid water, and suggested that stronger hydrogen bonds which lead to a higher viscosity was formed due to the broken hydrogen bonds after magnetization.

One of the recent technologies used to enhance the compressive strength and workability of concrete is using magnetized water instead of normal water in concrete mixes. This new technology has increased the compressive strength. Using magnetized water in concrete is best in terms of lower porosity and higher density. There is a rapid increase in the implementation of magnetized water technology on the eighties and nineties decades. This is due to the development of magnetic devices and their influences in concrete properties. Importance of the mechanical properties of magnetized water concrete has been used in many fields of civil, military construction, like airports and jetties. Most researchers concentrate to produce economical concrete with higher strength by using new philosophies of design methods, like using water which is magnetically treated. When normal water flows through magnetic field, some of the physical properties of water are changed. Also, the number of molecules in the water clusters will decreased to 6 or 5 molecules which will cause decrease in surface tension and an increase in the percentage of molecules contribute for the hydration process. In magnetic treated water, molecules will lose their attractive and repulsive forces and then oriented on a magnetic pole or electric charge. Neutralized molecules of water are more easily attracted to numerous electrostatic fields which naturally contained by cement grains. Hydration of cement is faster and more complete with magnetically treated water.

\section{MATERIALS AND TESTS}

\subsection{Test on cement}

Sulphate Resisting Cement (SRC) is used when the concrete is exposed to the risk of deterioration due to sulphate attack. It can be used for structural concrete whereas OPC or PPC or Slag Cement is usable under normal conditions. SRC is one type of Portland cement in which the amount of Tricalcium aluminate $(\mathrm{C} 3 \mathrm{~A})$ is restricted to lower than $5 \%$ and $(2 \mathrm{C} 3 \mathrm{~A}+$ $\mathrm{C} 4 \mathrm{AF}$ ) is lower than $25 \%$ to resist the sulphate attack.

Table 1. Chemical composition of sulphate resisting cement

\begin{tabular}{|c|c|c|c|c|}
\hline Si. No & Chemical composition & Units & Test results of cement & Requirement of IS 12330-1998 \\
\hline 1 & Loss on ignition & $\%$ & 1.10 & $5.00 \mathrm{Max}$ \\
\hline 2 & Mgo & $\%$ & 1.15 & $6.00 \mathrm{Max}$ \\
\hline 3 & Insoluble residue (IR) & $\%$ & 0.36 & $4.00 \mathrm{Max}$ \\
\hline 4 & $\mathrm{SO}_{3}$ & $\%$ & 2.04 & $2.50 \mathrm{Max}$ \\
\hline 5 & Lime saturation factor (LSF) & & 0.91 & $0.66-1.02$ \\
\hline 6 & $\mathrm{Chlorides}_{3}$ & $\%$ & 0.042 & $0.10 \mathrm{Max}$ \\
\hline 7 & $\mathrm{C}_{3} \mathrm{~A}$ & & 1.98 & $5.00 \mathrm{Max}$ \\
\hline 8 & $2 \mathrm{C}_{3} \mathrm{~A}+\mathrm{C}_{4} \mathrm{AF}$ & & 21.09 & $25.00 \mathrm{Max}$ \\
\hline 9 & $\mathrm{C}_{3} \mathrm{~S}$ & & 53.18 & -- \\
\hline 10 & $\mathrm{C}_{2} \mathrm{~S}$ & & 20.80 & --- \\
\hline
\end{tabular}

Table 2. Physical properties sulphate resisting cement

\begin{tabular}{|c|c|c|c|c|}
\hline Si. No & Test & Units & Result & Require-ment of IS 12330-1998 \\
\hline 1 & Standard consistency & Mm/\% water content & $5 / 30 \%$ & $30 \mathrm{~min}$ \\
\hline 2 & $\begin{array}{c}\text { Setting time by vicat methode } \\
\text { a) Initial } \\
\text { b) Final }\end{array}$ & $\begin{array}{c}\text { min } \\
\text { min }\end{array}$ & 150245 & $600 \mathrm{~min}$ \\
\hline 3 & Specific gravity of cement & & 3.5 & $3.2-3.5$ \\
\hline 4 & Fineness of cement & $\mathrm{m}^{2} / \mathrm{kg}$ & 281 & $225 \mathrm{Min}$ \\
\hline & Soundness test & $\mathrm{Mm}$ & Nil & $10 \mathrm{Max}$ \\
5 & a) Le-Chatlier & $\%$ & 0.03 & $0.80 \mathrm{Max}$ \\
\hline 6 & Expansion & $\%$ & 0.0064 & $0.045 \mathrm{Max}$ \\
\hline & b) Autoclave test & $\mathrm{Mpa}$ & 30.0 & $10.0 \mathrm{~min}$ \\
7 & Sulphate expansion & $\mathrm{Mpa}$ & 41.0 & $16.0 \mathrm{~min}$ \\
& Compressive strength & $\mathrm{Mpa}$ & 54.0 & $33.0 \mathrm{~min}$ \\
\hline
\end{tabular}




\subsection{Test on metakaolin}

MetaKaolin is used as binder for cementitious products. Give extra strength and good bonding for the materials [9].

Table 3. Chemical composition of metakaolin

\begin{tabular}{|c|c|c|c|}
\hline $\begin{array}{c}\text { Si. } \\
\text { No }\end{array}$ & Chemical composition & Units & $\begin{array}{c}\text { Test results of } \\
\text { metakaolin }\end{array}$ \\
\hline 1 & Loss on Ignition & $\%$ & 0.89 \\
\hline 2 & $\mathrm{MgO}$ & $\%$ & 0.03 \\
\hline 3 & Insoluble Residue (IR) & $\%$ & --- \\
\hline 4 & $\mathrm{SO}_{3}$ & $\%$ & --- \\
\hline 5 & $\mathrm{Na}_{2} \mathrm{O}$ & $\%$ & 0.13 \\
\hline 6 & $\mathrm{SiO}_{2}$ & $\%$ & 50.6 \\
\hline 7 & $\mathrm{Fe}_{2} \mathrm{O}_{3}$ & $\%$ & 0.32 \\
\hline 8 & $\mathrm{CaO}^{2}$ & $\%$ & 0.01 \\
\hline 9 & $\mathrm{SO}_{3}$ & $\%$ & --- \\
\hline 10 & $\mathrm{Cl}^{-}$ & $\%$ & --- \\
\hline
\end{tabular}

Table 4. Physical properties of Metakaoin

\begin{tabular}{|c|l|c|c|}
\hline Si. No & \multicolumn{1}{|c|}{ Test } & Units & Result \\
\hline 1 & Color & Nature & white \\
\hline 2 & Specific Surface area & $\mathrm{m}^{2} / \mathrm{kg}$ & 8.3 \\
\hline 3 & Specific gravity & & 2.6 \\
\hline 4 & BET & $\mathrm{m}^{2} / \mathrm{g}$ & 15 \\
\hline 5 & Average plastic size & $\mu \mathrm{m}$ & 3.2 \\
\hline 6 & Brightness & Hunter L & 81.2 \\
\hline
\end{tabular}

\subsection{Tests on fine aggregate}

River sand of Zone-II locally available is used, which is free from silt content and waste materials.

Table 5. Test results of fine aggregate

\begin{tabular}{|c|c|c|c|}
\hline $\begin{array}{c}\text { Si. } \\
\text { No }\end{array}$ & Test & $\begin{array}{c}\text { Standard } \\
\text { Codes }\end{array}$ & $\begin{array}{c}\text { Required } \\
\text { results }\end{array}$ \\
\hline 1 & Sieve analysis & IS-383 & Zone II \\
\hline 2 & Bulk density & IS-2386-part-3 & $1588 \mathrm{~kg} / \mathrm{l}$ \\
\hline 3 & Specific gravity & IS-2386-part-3 & 2.66 \\
\hline 4 & Moisture Content test & ASTM c70-13 & $5 \%$ \\
\hline 5 & Fineness modulus & IS-383 & Coarse sand \\
\hline
\end{tabular}

\subsection{Test on coarse aggregates}

Crushed stone aggregate of maximum size $12.5 \mathrm{~mm}$ passing and $10 \mathrm{~mm}$ retained are used.

Table 6. Test results of coarse aggregate

\begin{tabular}{|c|c|c|c|}
\hline $\begin{array}{c}\text { Si. } \\
\text { No }\end{array}$ & Test & IS: Code & $\begin{array}{c}\text { Required } \\
\text { results }\end{array}$ \\
\hline 1 & Sieve analysis & IS-2386-part-3 & $88 \%(85-100)$ \\
\hline 2 & Specific gravity & IS-2720-part-3 & 2.62 \\
\hline 3 & Angularity test & IS-2386-part-3 & $1494.1 \mathrm{~kg} / \mathrm{m}^{3}$ \\
\hline 4 & $\begin{array}{c}\text { Shape test- flakiness } \\
\text { index }\end{array}$ & IS-2386-part-1 & $11.55 \%$ \\
\hline 5 & $\begin{array}{c}\text { Shape test- } \\
\text { Elongation index }\end{array}$ & IS-2386-part-1 & $12.79 \%$ \\
\hline & \multicolumn{2}{|l}{} \\
\hline
\end{tabular}

\begin{tabular}{|c|c|c|c|}
\hline 6 & $\begin{array}{c}\text { Bulk density: } 12.5 \\
\text { mm loose } \\
\text { mm compacted }\end{array}$ & & $16.32 \mathrm{~kg} / \mathrm{l}$ \\
\hline 7 & $\begin{array}{c}\text { Aggregate abrasion } \\
\text { test }\end{array}$ & IS-2386-part-4 & $25.82 \%$ \\
\hline 8 & Impact test & IS-2386-part-4 & $\begin{array}{c}13.36 \% \\
(<30 \%)\end{array}$ \\
\hline 9 & Crushing test & IS-2386-part-4 & $\begin{array}{c}1.64 \% \\
(<30 \%)\end{array}$ \\
\hline 10 & $\begin{array}{c}\text { Water absorption } \\
\text { test }\end{array}$ & IS-2386-part-3 & $2 \%$ \\
\hline
\end{tabular}

\subsection{Preparation \& test water}

The results of tests conducted on normal water and magnetic water, are listed below in the table. In the present investigation work, magnetic water was prepared by placing magnets into the beaker containing water of 985 Gauss magnetic field that was obtained from scientific store. This Magnetic water was produced by placing the beaker filled with water over the magnets for a period of 24 hours. During this time, the magnetic field penetrates through the glass into the water and this magnetized water is used for making concrete [10].

Table 7. Test results of water

\begin{tabular}{|c|c|c|c|}
\hline Si. No & Test & Normal water & Magnetic water \\
\hline 1 & Temperature & $28.4 \mathrm{C}$ & $28.2 \mathrm{C}$ \\
\hline 2 & $\mathrm{pH}$ & 8 & 7.6 \\
\hline 3 & $\begin{array}{c}\text { Magnetic field } \\
\text { Intensity }\end{array}$ & 1850 gauss & 2107 gauss \\
\hline 4 & T.D.S & $450 \mathrm{mg} / \mathrm{l}$ & $300 \mathrm{mg} / \mathrm{l}$ \\
\hline 5 & Hardness & $\begin{array}{c}160 \mathrm{mg} / \mathrm{l} \text { of } \\
\mathrm{CaCO}_{3}\end{array}$ & $\begin{array}{c}140 \mathrm{mg} / \mathrm{l} \text { of } \\
\mathrm{CaCO}_{3}\end{array}$ \\
\hline
\end{tabular}

\subsection{Micro steel fibers}

The below mentioned specified micro steel fibers are used in the project to improve the strength characteristics of concrete.

Table 8. Properties of micro steel fiber

\begin{tabular}{|c|c|c|c|}
\hline Si. No & Properties & Units & values \\
\hline 1 & Diameter & $\mathrm{mm}$ & $0.15-0.22$ \\
\hline 2 & Length & $\mathrm{mm}$ & $6-8$ \\
\hline 3 & Tensile strength & $\mathrm{Mpa}$ & $>2500$ \\
\hline 4 & Aspect ratio & - & 50 \\
\hline 5 & Young's Modulus & $\mathrm{Gpa}$ & 280 \\
\hline 6 & Shape & Nature & Stright \\
\hline 7 & Density & $\mathrm{Kg} / \mathrm{m}^{3}$ & 7950 \\
\hline
\end{tabular}

\subsection{Super plasticizer}

It is used for reducing the water- cement ratio of concrete. Specific Gravity of super plasticizer is 1.04.

\section{EXPERIMENTATION}

The Experimentation has done in four different stages in that

Stage - 1 To find out the optimum percentage of admixture by four different trails $(0.6 \%, 0.7 \%, 0.8 \%, 0.9 \%)$. 
Stage -2 By considering the optimum percentage of admixture, preceding to find the Maximum percentage of steel fibers $(0.5 \%, 0.75 \%, 1 \%, 1.5 \%, 1.75 \%, 2 \%)$.

Stage -3 By keeping the admixture content at optimum, finding out the optimum metakaolin Percentage (1\%, $2 \%, 3 \%$, $4 \%, 5 \%)$.
Stage -4 Now, by taking optimum values of admixture, steel fiber and metakaolin

(a) Making a trail (C.G), using general water

(b) Making a trail (C.M), using magnetic water

The mix design for self-compacting concrete M40 grade is made according to code of practice ASTM C-904.

Table 9. Proportions of mix design

\begin{tabular}{|c|c|c|c|c|c|}
\hline Si. No & Cement & Fine aggregate & Coarse aggregate & W/C ratio & Super plasticizer \\
\hline 1 & 550 & 770.47 & 948.90 & 165 & 4.4 \\
\hline & 1 & 1.400 & 1.172 & 0.30 & $0.8 \%$ \\
\hline
\end{tabular}

\section{RESULTS AND DISCUSSIONS}

Test series consisted of 108 cubes and 54 cylinders of 18 different mixes at 18 different ratios of materials. The dimensions of cube specimens are $150 \mathrm{~mm} \times 150 \mathrm{~mm} \times 150$ $\mathrm{mm}$ and cylinder specimen having dimensions of $300 \mathrm{~mm}$ height, $150 \mathrm{~mm}$ diameter Tests were conducted after curing the specimens for 7, 14 and 28 days respectively.
Graphs are plotted between compressive strength and \% of Admixture added to the mix proportion. Here the compressive strength values varied in 7 Days, 14Days and 28-days is shown in Figure 1.

Graphs are plotted between compressive strength and \% of steel fibers added to the mix proportion. Here the compressive strength values varied in 7 Days, 14 Days and 28Days is shown in Figure 2.

Table 10. S.C.C test results for admixture trials where AM is the admixture

\begin{tabular}{|c|c|c|c|c|c|c|c|}
\hline Mix design & \% AD & Slump test (mm) & T50 slump (sec) & L- Box (sec) & V- funnel (sec) & J-ring (mm/ sec) & U- funnel (sec) \\
\hline AM-1 & 0.6 & 610 & 2.0 & 8 & 9 & $620 / 9$ & 22 \\
\hline AM-2 & 0.7 & 600 & 1.6 & 9 & 8 & $640 / 8$ & 18 \\
\hline AM-3 & 0.8 & 640 & 1.8 & 10 & 10 & $600 / 7$ & 20 \\
\hline AM-4 & 0.9 & 620 & 1.7 & 8 & 8 & $610 / 8$ & 24 \\
\hline
\end{tabular}

Note: AM is the admixture; same as below.

Table 11. Admixture optimum test results of compressive strength

\begin{tabular}{|c|c|c|c|c|c|}
\hline Si. No & Mix design & \% Admixture & 7-Days Mpa & 14-Days Mpa & 28-Days Mpa \\
\hline 1 & AM-1 & 0.6 & 33.4 & 42.2 & 45.2 \\
\hline 2 & AM-2 & 0.7 & 35.7 & 44.4 & 47.5 \\
\hline 3 & AM-3 & 0.8 & 40.6 & 46.2 & 50.7 \\
\hline 4 & AM-4 & 0.9 & 36.2 & 42.2 & 46.7 \\
\hline
\end{tabular}

Table 12. S.C.C test results for steel fiber trails

\begin{tabular}{|c|c|c|c|c|c|c|c|}
\hline Mix design & \% Steel fiber & Slump test (mm) & T50 slump (sec) & L- Box(sec) & V-funnel(sec) & J-ring(mm/sec) & U- funnel(sec) \\
\hline SF-1 & 0.5 & 620 & 1.8 & 9 & 8 & $600 / 7$ & 24 \\
\hline SF-2 & 0.75 & 640 & 1.7 & 8 & 8 & $620 / 9$ & 18 \\
\hline SF-3 & 1 & 650 & 2.0 & 8 & 9 & $610 / 8$ & 19 \\
\hline SF-4 & 1.5 & 700 & 2.0 & 9 & 9 & $640 / 9$ & 23 \\
\hline SF-5 & 1.75 & 680 & 1.9 & 9 & 8 & $620 / 8$ & 20 \\
\hline SF-6 & 2 & 650 & 1.8 & 8 & 9 & $640 / 9$ & 24 \\
\hline
\end{tabular}

Note: SF is the steel fiber; same as below.

Table 13. Steel fibers test results of compressive strength

\begin{tabular}{|c|c|c|c|c|c|}
\hline Si. No & Mix design & \% Steel fiber & 7-Days Mpa & 14-Days Mpa & 28-Days Mpa \\
\hline 1 & SF-1 & 0.5 & 41 & 48.1 & 52 \\
\hline 2 & SF-2 & 0.75 & 42.5 & 50.2 & 53.4 \\
\hline 3 & SF-3 & 1 & 44 & 50.8 & 55 \\
\hline 4 & SF-4 & 1.5 & 48 & 51 & 56.2 \\
\hline 5 & SF-5 & 1.75 & 45.1 & 49 & 52 \\
\hline 6 & SF-6 & 2 & 43.6 & 45.4 & 51.2 \\
\hline
\end{tabular}

Table 14. S.C.C test results for metakaolin trails

\begin{tabular}{|c|c|c|c|c|c|c|c|}
\hline Mix design & \%Mk & Slump test (mm) & T50 slump(sec) & L- Box(sec) & V-funnel(sec) & J-ring(mm/sec) & U-funnel(sec) \\
\hline M-1 & 1 & 630 & 1.2 & 8 & 8 & $630 / 8$ & 22 \\
\hline M-2 & 2 & 650 & 1.3 & 9 & 9 & $640 / 9$ & 20 \\
\hline
\end{tabular}




\begin{tabular}{|l|l|l|l|l|l|l|l|}
\hline M-3 & 3 & 640 & 1.5 & 8 & 8 & $610 / 8$ & 24 \\
\hline M-4 & 4 & 650 & 1.8 & 10 & 8 & $620 / 7$ & 23 \\
\hline M-5 & 5 & 660 & 2.0 & 9 & 9 & $640 / 8$ & 22 \\
\hline
\end{tabular}

Note: MK is the metakaolin

Table 15. Metakaolin test results of compressive strength

\begin{tabular}{|c|c|c|c|c|c|}
\hline Si. No & Mix design & \% Metakaolin & 7-Days Mpa & 14-Days Mpa & 28-Days Mpa \\
\hline 1 & M-1 & 1 & 40.8 & 49.2 & 51 \\
\hline 2 & M-2 & 2 & 41.6 & 50 & 53.2 \\
\hline 3 & M-3 & 3 & 44 & 50.4 & 54.5 \\
\hline 4 & M-4 & 4 & 46.2 & 54 & 55.2 \\
\hline 5 & M-5 & 5 & 45.2 & 51.2 & 52.1 \\
\hline
\end{tabular}

Table 16. S.C.C test results on combination trail with general and magnetic water

\begin{tabular}{|c|c|c|c|c|c|c|}
\hline Mix design & Slump test (mm) & T50 slump (sec) & L- Box (sec) & V- funnel (sec) & J-ring (mm/ sec) & U- funnel (sec) \\
\hline CG & 630 & 1.2 & 8 & 8 & $630 / 8$ & 22 \\
\hline CM & 650 & 1.3 & 9 & 9 & $640 / 9$ & 20 \\
\hline
\end{tabular}

Note: $\mathrm{CG}=$ combination with general water; $\mathrm{CM}=$ combination with magnetic water.

Table 17. Compressive strength on combination trail with general and magnetic water

\begin{tabular}{|c|c|c|c|c|}
\hline Si. No & Mix design & 7-days Mpa & 14-days Mpa & 28-days Mpa \\
\hline 1 & CG & 55.2 & 66 & 70.2 \\
\hline 2 & CM & 58.3 & 69.9 & 77.5 \\
\hline
\end{tabular}

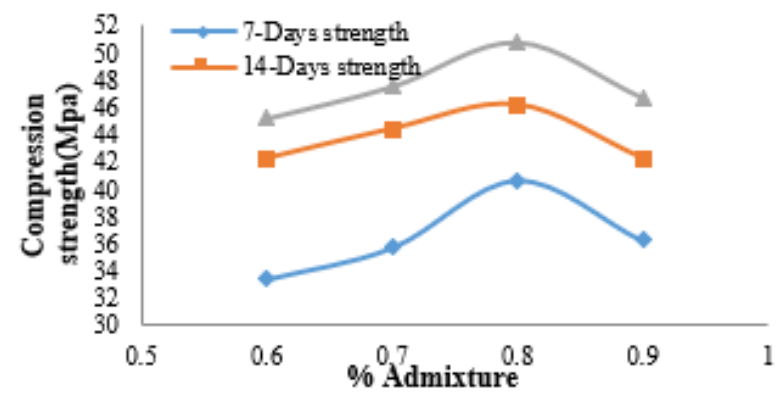

Figure 1. Graph between \% admixture and compression strength

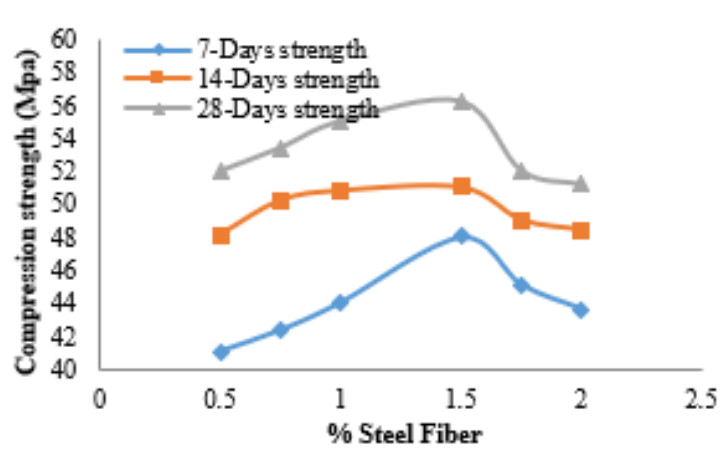

Figure 2. Graph between \% steel fiber and Compression strength

Table 18. S.C.C test results for cylinder trails

\begin{tabular}{|c|c|c|c|c|c|c|}
\hline Sample & Slump test (mm) & T50 slump(sec) & L- Box(sec) & V-funnel(sec) & J-ring(mm/sec) & U- funnel (sec) \\
\hline Admixture & 630 & 1.2 & 8 & 8 & $630 / 8$ & 22 \\
\hline Steel fiber & 650 & 1.3 & 9 & 9 & $640 / 9$ & 20 \\
\hline Metakaolin & 640 & 1.5 & 8 & 8 & $610 / 8$ & 24 \\
\hline Comb + general water & 650 & 1.8 & 10 & 8 & $620 / 7$ & 23 \\
\hline Comb + Magnetic water & 660 & 2.0 & 9 & 9 & $640 / 8$ & 22 \\
\hline
\end{tabular}

Table 19. Tensile strength results

\begin{tabular}{|c|c|c|c|c|c|c|}
\hline \multirow{2}{*}{ Sample } & \multicolumn{2}{|c|}{ 7-days } & \multicolumn{2}{|c|}{ 14-days } & \multicolumn{2}{|c|}{ 28-days } \\
\hline & $\operatorname{Load}\left(\mathbf{N} / \mathbf{m m}^{2}\right)$ & T.S Mpa & $\operatorname{Load}\left(\mathrm{N} / \mathbf{m m}^{2}\right)$ & T.S Mpa & $\operatorname{Load}\left(\mathrm{N} / \mathbf{m m}^{2}\right)$ & T.S Mpa \\
\hline $\mathrm{AD}$ & 210 & 2.97 & 265 & 3.74 & 285 & 4.03 \\
\hline Steel fiber & 235 & 3.24 & 300 & 4.24 & 322 & 4.55 \\
\hline Meta kaolin & 220 & 3.11 & 280 & 3.96 & 291 & 4.11 \\
\hline Comb + General water & 260 & 3.67 & 320 & 4.52 & 348 & 4.92 \\
\hline Comb + Magnetic water & 282 & 3.98 & 345 & 4.88 & 365 & 5.16 \\
\hline
\end{tabular}




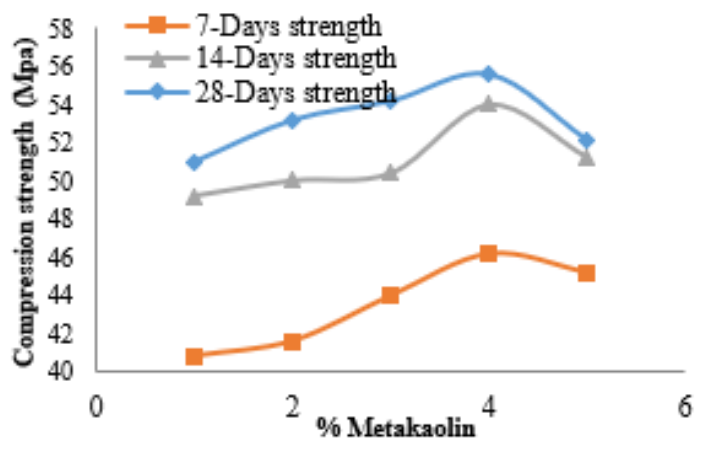

Figure 3. Graph between \% metakaolin and compression strength

Graphs are plotted between compressive strength and \% of metakaolin added to the proportion of mix. Here the compressive strength values shown at is shown in Figure 3.

\section{COST ANALYSIS}

Table 20. Cost analysis for magnetic water self compacting concrete

\begin{tabular}{|c|c|c|c|c|}
\hline Materials & Rate & Unit & Quantity & Amount \\
\hline Cement & INR 270 & Bag (50 kg) & 10 & INR 2700 \\
\hline Sand & INR 800 & MT & 0.770 & INR 616 \\
\hline Aggregate & INR 650 & MT & 0.948 & INR646.2 \\
\hline water & INR 250 & 8000 lt & 165 & INR 5.15 \\
\hline Plasticizer & INR 20 & Lt & 4.4 & INR 44 \\
\hline Steel fiber & INR 8.5 & Kg & 20 & INR 170 \\
\hline MetaKaolin & INR 15 & Kg & 5.5 & INR 82.5 \\
\hline Miscellaneous chargers & & & INR 400 \\
\hline \multicolumn{5}{|c|}{ Total } \\
\hline
\end{tabular}

In general M40 grade self compacting concrte on market price is 5000 .

In cost comparision wise Magnetic water self compacting concrete is less compair to Self Compacting Concrete.

Table 21. Cost comparsion of SCC \& MWSCC

\begin{tabular}{|c|c|c|c|c|c|}
\hline $\begin{array}{c}\text { Si. } \\
\text { No }\end{array}$ & $\begin{array}{c}\text { Mix } \\
\text { Design }\end{array}$ & $\begin{array}{c}\text { Cost of } \\
\text { SCC }\end{array}$ & $\begin{array}{c}\text { Cost of } \\
\text { MWSCC }\end{array}$ & $\begin{array}{c}\text { Excess } \\
(\boldsymbol{\%})\end{array}$ & $\begin{array}{c}\text { Less } \\
(\boldsymbol{\%})\end{array}$ \\
\hline 1 & M40 & $\begin{array}{c}\text { INR } \\
5000\end{array}$ & INR 4663 & --- & 6.74 \\
\hline
\end{tabular}

Note: SCC means Self Compacting Concrete; MWSCC means Magnetic Water Seelf Compacting Concrete.

\section{CONCLUSIONS}

This paper explains how the influence of magnetic water influences self compacting and how it strengthens the characteristics of concrete. Due to this purpose, 985 gauss magnetic strength is used to prepare magnetic water. The conclusions based on the above research on this paper are stated as given below:

- The workability of SCC made by magnetic water is observed to be moderately more than that of general water at same water cement ratio. It may be due to the fact that by keeping magnets with water, inter molecular changes occurs, which results in the decrease of $\mathrm{pH}$, hardness and turbidity.

- It is evident from the test results that the Compressive strength of SCC made by magnetic water is higher than that of non magnetic water by $10 \%$.

- It is also observed that the Tensile strength of SCC with magnetic water is increased by $5 \%$ than SCC with normal water.

- In cost comparison wise Magnetic water self compacting concrete is less than $6.74 \%$ when compare to self compacting Concrete.

\section{ACKNOWLEDGMENT}

This work had been endorsed by the Research on Polypropylene Foam, Development and innovation in Undergraduate studies at Vignan's Lara Institute Technology \& Science.And also special thanks to "L.C.C Ready mix Concrete Pvt Ltd, Gunntur".

\section{REFERENCES}

[1] Domone, P.L. (2007). A review of the hardened mechanical properties of self-compacting concrete. Cement and Concrete Composites, 29(1): 1-12. https://doi.org/10.1016/j.cemconcomp.2006.07.010

[2] Ministry of Housing and Urban-Rural Development of the People's Republic of China. (2012). Technical Specification for Application of Self-Compacting Concrete.

[3] Wu, Z.W., Lian, H.Z. (1999). High Performance Concrete. China Railway Press, Beijing.

[4] Hajime, O., Ouchi, M. (2003). Self-compacting concrete. J. Adv. Concr. Technol., 1(1): 5-15.

[5] State Construction Committee of Russia. (1993). Application of Magnetic Fields in National Economy, Issued No.1058.

[6] Su, N., Wu, C.F. (2003). Effect of magnetic field treated water on mortar and concrete containing fly ash. Cement and Concrete Composites, 25(7): 681-688. https://doi.org/10.1016/S0958-9465(02)00098-7

[7] Singh, S.P., Kaushik, S.K. (2001). Fatigue strength of steel fibre reinforced concrete in flexure. ACI Material Journal, 98(4): 306-312. https://doi.org/10.1016/s09589465(02)00102-6

[8] Mehta, P.K. (1993). Sulfate attack on concrete - A critical review. Materials Science of Concrete III, American Ceramic Society, Westerville, OH, pp. 105-130.

[9] Sabir, B.B., Wild, S., Bai, J. (2001). Metakaolin and calcined clay as pozzolans for concrete: A review. Cement and Concrete Composite, 23(6): 441-454. https://doi.org/10.1016/S0958-9465(00)00092-5

[10] Wang, Y.K., Wei, H.N., Li, Z.W. (2017). Effect of magnetic field on the physical properties of water. Results in Physics, 8: 262-267. https://doi.org/10.1016/j.rinp.2017.12.022

[11] Kotb, A., Abd El Aziz, A.M. (2013). Scientific investigations on the claims of the magnetic water conditioners. Scientific Investigations on the Claims of the Magnetic Water Conditioners, 2(1): 16-27. 